\title{
EFFECT OF TOXICITY OF NEEM (AZADIRACHTA INDICA A. JUSS) AND MOHANEEM (MELIA AZEDARACH LINNAEUS) ON THE LARVAE OF MOSQUITO CULEX QUINQUEFASCIATUS (SAY) (DIPTERA: CULICIDAE)
}

\author{
HUMAYUN REZA KHAN, JINIFATH-IR-RAHMAN, TAIYEBA \\ TANJINA AND HUMAYERA AFIA \\ Department of Zoology, University of Dhaka, Bangladesh
}

\begin{abstract}
The larvicidal activities of three solvent extracts, viz. ethanol, chloroform and water of two plants neem Azadirachta indica (A. Juss) and mohaneem Melia azedarach (Linn.) against the fourth instar larvae of mosquito Culex quinquefasciatus (Say) (Diptera: Culicidae) were studied in the laboratory at $27 \pm 2{ }^{\circ} \mathrm{C}$ and $75-85 \% \mathrm{RH}$. No larval mortality was observed in control treatment. The larval mortalities by the ethanol extracts of $A$. indica at the five dose concentrations were 37.33, 64.00, 64.00, 76.00 and $97.33 \%$, respectively; by the chloroform extracts were $24.00,54.66,80.00,96.00$ and $100 \%$, respectively; by the water extracts were $32.00,56.00,62.66,68.00$ and $81.33 \%$, respectively. The larval mortalities by the ethanol extracts of $M$. azedarach at the five dose concentrations were $29.33,58.66,64.00,74.66$ and $89.33 \%$, respectively; by the chloroform extracts were $40.00,49.33,61.33,73.33$ and $84.00 \%$, respectively; by the water extracts were $29.33,58.66,64.00,74.66$ and $89.33 \%$, respectively. In case of $A$. indica, $\mathrm{LC}_{50}, \mathrm{LC}_{90}$ and $\mathrm{LC}_{99}$ values for the ethanol extracts were $1.805,3.581$ and 6.261 $\mathrm{mg} / \mathrm{ml}$, respectively; for the chloroform extracts were $0.686,1.112$, and $1.648 \mathrm{mg} / \mathrm{ml}$, respectively; and for the water extracts were $3.002,5.584$ and $9.262 \mathrm{mg} / \mathrm{ml}$, respectively. In case of $M$. azedarach, $\mathrm{LC}_{50}, \mathrm{LC}_{90}$ and $\mathrm{LC}_{99}$ values for the ethanol extracts were 1.949, 3.89 and $6.835 \mathrm{mg} / \mathrm{ml}$, respectively; for the chloroform extracts were $0.695,2.256$, and $5.886 \mathrm{mg} / \mathrm{ml}$, respectively; and for the water extracts were $3.536,6.662$ and 10.866 $\mathrm{mg} / \mathrm{ml}$, respectively.
\end{abstract}

Key words: Azadirachta indic, Melia azedarach, Cx. Quinquefasciatus, Toxicity, Lethal concentration

\section{Introduction}

Mosquitoes transmit more diseases than any other group of arthropods affecting millions of people throughout the world (Ghosh et al. 2012) and causing millions of deaths every year (Kamaraj et al. 2011). The World Health Organization (WHO) has declared mosquito as "public enemy number one" (Ghosh et al. 2012) because it is the principal vector of many of the "vector-borne" diseases affecting human beings and other animals (Ravichandran et al. 2014). Several mosquito species of the genera Aedes, Anopheles and Culex are vectors for the pathogen of various diseases like malaria, yellow fever, dengue, chikungunya, Zika, West Nile, Japanese encephalitis and filariasis (Kazembe and Makusha 2012).

In Bangladesh Ahmed (1987) reported 25 species of Culex and recorded 22 species of mosquitoes related to medico-veterinary importance among which eight species belonged to 
Culex. In Dhaka city, the population of Cx. quinquefasciatus is peaked during the dry season from November to December (Khan et al. 2015). Begum et al. (1996) studied the larval population of $C x$. quinquefasciatus in Dhaka city and its suburbs. Recently, Khan et al. (2014 and 2015) reported 13 species of mosquito in five wards of Dhaka city of which Culex quinquefasciatus was the predominant one.

Botanicals as potential insecticides were studied for the first time in the country by Ameen et al. (1985) and Ameen et al. (1983a and b); they bioassayed the solvent based root extracts of Derris elliptica plant on the larvae of two mosquito species of the genera Aedes and Culex. The principal toxicant of D. elliptica as insecticide is rotenone. Neem, Azadirachta indica, is a member of the family Meliaceae, which has been reported to contain several biologically active constituents, such as azadirachtin, meliantriol, salanin, nimbin and nimbidin (Naganishi 1975 and Aliero 2003). Mohaneem, M. azedarach, is another member of the family Meliaceae which contains azadirachtin, meliantriol steroids, tarpenoids, saponins and tannins (Azam et al. 2013 and Ahmed et al. 2012). Among the chemicals, azadirachtin showed maximum biological activity (95\%) against the larvae, pupae and adult of $A$. stephensi (Nathan et al.2005). Nour et al. (2012) tested acetone, chloroform and ethanolic extracts of the bark, root, leaf and seeds of A. indica against the larvae of Ae. Aegypti. Batabyal et al. (2007) tested petroleum ether, carbon tetra-chloride and methanol extracts from the seeds of $A$. indica against the larvae of An. stephensi. The methanolic leaf and seed extracts of $M$. azedarach were tested against An. stephensi for its larvicidal, pupicidal, adulticidal, oviposition deterrent and repellent activities by Nathan et al. (2006). The fruit extracts of M. azedarach and A. indica elicit a variety of effects in insects, such as antifeedant, growth retardation, reduced fecundity, moulting disorders, morphogenetic defects and changes of behavior (Wandscheer et al. 2004). Alouani et al. (2009) studied the effects of azadirachtin of neem on the fourth instar larvae of $C x$. pipens at different concentrations and reported that $A$. indica was potentially more effective to mosquito control than that of $M$. azedarach.

Since neem and mohaneem plants are easily available in the country and since they have immense potentiality as the source of botanical insecticides, the objective of the present paper was, therefore, to assess the three solvent extracts of each of the two plant species $A$. indica and M. azedarach on the larvae of $C x$. quinquefasciatus (Say).

\section{Materials and Methods}

After the collection of larvae of $C x$. quinquefasciatus, rearing of the larvae into adults, collection of the leaves of neem and mohaneem, extraction process of the leaves, and bioassay tests were conducted from September 2015 to March 2016 at the Entomology Research Laboratory of the Department of Zoology, University of Dhaka and also in the Center for Advanced Research in Sciences (CARS), University of Dhaka.

Collection and rearing of larvae and adults in the laboratory: The larvae of the mosquito $C x$. quinquefasciatus were collected from some potential breeding places in Dhaka city, such as the drains of Curzon Hall area, Dhaka University. These were then reared in the laboratory at $27 \pm 2{ }^{\circ} \mathrm{C}$ and $75-85 \% \mathrm{RH}$. The procedure of rearing of $C x$. quinquefasciatus was done following Bilkis (1997). During rearing the larvae were served with yeast powder while the emerged adults were provided with $10 \%$ glucose solutions as their food. After pupation, the 
pupae were transferred to small plastic containers and then to an adult rearing cage $(30 \mathrm{~cm} \mathrm{x}$ $30 \mathrm{~cm} \times 30 \mathrm{~cm}$ ) for emergence. After 3-4 days of emergence, the adult female mosquitoes were given a blood meal from a pigeon, Columba livia for egg maturation. A petridish containing tap water was placed inside the cage for the females to oviposit. After couple of days, the females laid egg rafts on the surface of water of the petridish. Then the egg masses were allowed to hatch into the first instar larvae which were subsequently moulted into $2^{\text {nd }}$, $3^{\text {rd }}$ and $4^{\text {th }}$ instar larvae and pupae, and finally emerged into adults. In this way the rearing process continued for several generations for obtaining adequate number of larvae for bioassay tests with plant extracts of neem and mohaneem.

Preparation of plant extract: The leaves of neem A. indica and mohaneem M. azedarach were collected from these trees located in the premises of Curzon Hall, Dhaka University. Both the plant species were authenticated from the Botany Department, Dhaka University. The collected leaves were washed with tap water, sun-dried for seven days, and then powdered by using an electrical blender. Each $50 \mathrm{~g}$ of the leaf powder of neem and mohaneem was dissolved separately in $300 \mathrm{ml}$ of ethanol, chloroform and water, and kept for 24 hours with periodic shaking in a Shaking Orbital Machine at $100 \mathrm{rpm}$ and $30^{\circ} \mathrm{C}$, then filtered and the sample solutions were collected. This procedure was repeated three times with fresh volume of respective solvents. The total volumes of the samples were concentrated separately in a Rotary Vacuum Evaporator machine. The water in the samples was completely evaporated and dried at $200 \mathrm{rpm}$ and $60^{\circ} \mathrm{C}$, and the ethanol and chloroform samples were at $100 \mathrm{rpm}$ and $40{ }^{\circ} \mathrm{C}$; these dried extracts were then stored at $4{ }^{\circ} \mathrm{C}$ in an air tight white glass bottle for future use in dose preparation.

Dose preparation and bioassay test: The fourth instar larvae of $C x$. quinquefasciatus were exposed to test doses of 150, 200, 250, 300 and $350 \mathrm{mgs}$ each of the ethanol based extracts, $50,75,100,125$ and $150 \mathrm{mgs}$ each of the chloroform based extracts, and finally 250, 300, 350,400 and $450 \mathrm{mgs}$ each of the water based extracts of the leaves of both $A$. indica and $M$. azedirach. The concentrations of the above doses calculated were: 1.5, 2.0. 2.5, 3.0 and 3.5 $\mathrm{mg} / \mathrm{ml}$, respectively for the ethanol extracts; $0.5,0.75,1.0,1.25$ and $1.50 \mathrm{mg} / \mathrm{ml}$, respectively for the chloroform extracts; and 2.5, 3.0, 3.5, 4.0 and $4.5 \mathrm{mg} / \mathrm{ml}$, respectively for the water extracts. For each of the dose concentrations, 25 fourth instar larvae of $C x$. quinquefasciatus were exposed and three replicates were maintained for each case. The measured amount of the extracts was dissolved in $2 \mathrm{ml}$ of dimethyl sulfoxide (DMSO) which was used to solubilize the plant extracts in water as suggested by Nour et al. (2012), but the water extracts were dissolved directly in water and no DMSO was required to add into it. Each of the dissolved plant extracts in DMSO was added to $100 \mathrm{ml}$ water in a beaker. A set of control, using 2.0\% DMSO as Control 1 and an untreated set of larvae in water (tap) as Control 2, were also used for comparison. The larvae were fed with dry yeast powder sprinkled on the surface of water at the rate of $50 \mathrm{mg} / \mathrm{ml}$.

The mortality of the larvae was recorded after 36 hours of exposure and moribund larvae were counted as dead. The toxicity of the plant extracts was calculated in the form of $\mathrm{LC}_{50}, \mathrm{LC}_{90}$ and $\mathrm{LC}_{99}$ values, which indicate 50, 90 and 99 per cents death of test larvae, respectively. The recorded mortality percentage values were calculated by using the formula-

Percentage mortality $=\frac{\text { Number of larvae died }}{\text { Number of test larvae }} \times 100$ 
When mortality in control treatment was more than $5 \%$, the percentage mortality was corrected by using Abbott's (1925) formula-

$$
\begin{aligned}
& \text { Corrected mortality }= \\
& \frac{\text { Larval mortality in the treatment - Larval mortality in control }}{100 \text {-control mortality }} \times 100
\end{aligned}
$$

Statistical analysis: $\mathrm{LC}_{50}, \mathrm{LC}_{90}$ and $\mathrm{LC}_{99}$ values at $95 \%$ confidence intervals of lower and upper confidence limits were calculated by following the probit analysis method suggested by Finney (1971). Other statistics like chi-square values, regression at $95 \%$ confidence intervals of upper and lower confidence limits and t-tests were calculated using the IBM SPSS statistics 20 (Statistical Package of Social Science) software; here significance levels were set at $\mathrm{p}<0.05$.

\section{Results and Discussion}

After 36 hours of exposure, the larval mortalities at five different concentrations of three solvent extracts of $A$. indica and $M$. azedarach are presented in Table 1 and no mortality was observed in control treatments.

$\mathrm{LC}_{50}, \mathrm{LC}_{90}$ and $\mathrm{LC}_{99}$ values in relation to the larval mortalities of $C x$. quinquefasciatus due to the effects of solvent extracts of neem and mohaneem leaves and their lower and higher confidence limits at $95 \%$, and chi-square test values were calculated and the results are presented in Table 2 .

Comparison of toxicity of different solvents based extracts of neem and mohaneem: The values of $\mathrm{LC}_{50}, \mathrm{LC}_{90}$ and $\mathrm{LC}_{99}$ show that the water extracts of neem (A. indica) and mohaneem (M. azedarach) were least toxic to the mosquito larvae followed by the ethanol extracts which was again followed by Chloroform extracts (Fig. 1). For neem and mohaneem leaf extracts, the grading of $\mathrm{LC}_{50}$ for these three solvent extracts on the basis of their toxicity is as follows: neem, Chloroform (0.686) > ethanol (1.805) > water

(3.002); mohaneem, Chloroform (0.695) > ethanol (1.949) > water (3.536). The grading

Table 1. Mean percentage mortality of larvae of $C x$. quiquefasciatus exposed to different

\begin{tabular}{|c|c|c|c|c|c|}
\hline \multicolumn{2}{|l|}{ Solvens } & \multicolumn{2}{|l|}{$\begin{array}{c}\text { Azadirachta } \\
\text { indica }\end{array}$} & \multicolumn{2}{|l|}{$\begin{array}{c}\text { Melia } \\
\text { azedarach }\end{array}$} \\
\hline & $\begin{array}{l}\text { Concentration } \\
(\mathrm{mg} / \mathrm{ml})\end{array}$ & $\begin{array}{l}\text { Mean no. of } \\
\text { larvae died } \\
(\text { Mean } \pm S D)\end{array}$ & $\begin{array}{l}\text { Mean \% of } \\
\text { larvae died }\end{array}$ & $\begin{array}{l}\text { Mean no. of } \\
\text { larvae died } \\
(\text { Mean } \pm S D)\end{array}$ & $\begin{array}{l}\text { Mean \% of } \\
\text { larvae died } \\
(\text { Mean } \pm \text { SD) }\end{array}$ \\
\hline \multirow[t]{3}{*}{ Ethanol } & Control & $0.00 \pm 0.00$ & 0.00 & $0.00 \pm 0.00$ & 0.00 \\
\hline & 1.50 & $9.33 \pm 1.33$ & 37.33 & $7.33 \pm 1.33$ & 29.33 \\
\hline & 2.00 & $16.00 \pm 1.00$ & 64.00 & $14.66 \pm 0.33$ & 58.66 \\
\hline
\end{tabular}
concentrations of three solvent leaf crude extracts of $A$. indica and M. azedarach. 


\begin{tabular}{rrrrrr}
2.50 & $16.00 \pm 0.00$ & 64.00 & $16.00 \pm 1.00$ & 64.00 \\
3.00 & $19.00 \pm 1.00$ & 76.00 & $18.66 \pm 0.33$ & 74.66 \\
3.50 & $24.33 \pm 1.33$ & 97.33 & $22.33 \pm 0.33$ & 89.33 \\
Chloroform & Control & $0.00 \pm 0.00$ & 0.00 & $0.00 \pm 0.00$ & 0.00 \\
0.5 & $6.00 \pm 1.00$ & 24.00 & $10.00 \pm 1.00$ & 40.00 \\
0.75 & $13.66 \pm 2.33$ & 54.66 & $12.33 \pm 0.33$ & 49.33 \\
1.00 & $20.00 \pm 1.00$ & 80.00 & $15.33 \pm 0.33$ & 61.33 \\
1.25 & $24.00 \pm 1.00$ & 96.00 & $18.33 \pm 0.33$ & 73.33 \\
1.50 & $25.00 \pm 0.00$ & 100 & $21.00 \pm 1.00$ & 84.00 \\
Control & $0.00 \pm 0.00$ & 0.00 & $0.00 \pm 0.00$ & 0.00 \\
2.50 & $8.00 \pm 1.00$ & 32.00 & $6.00 \pm 1.00$ & 29.33 \\
3.00 & $14.00 \pm 1.00$ & 56.00 & $9.00 \pm 1.00$ & 58.66 \\
3.50 & $15.66 \pm 0.33$ & 62.66 & $12.66 \pm 2.33$ & 64.00 \\
4.00 & $17.00 \pm 1.00$ & 68.00 & $14.33 \pm 1.33$ & 74.66 \\
4.50 & $23.00 \pm 2.33$ & 81.33 & $17.66 \pm 0.33$ & 89.33 \\
& & & & \\
\hline
\end{tabular}

SD standard deviation.

Table 2. $\mathrm{LC}_{50}, \mathrm{LC}_{90}, \mathrm{LC}_{99}$ and chi square values of the larvicidal activities of leaf extracts of A. indica and M. azaderach on the larvae of Cx. quinquefasciatus.

\begin{tabular}{|c|c|c|c|c|}
\hline $\begin{array}{l}\text { Plant and } \\
\text { Solvents }\end{array}$ & $\begin{array}{l}\mathrm{LC}_{50}(\mathrm{mg} / \mathrm{ml}) \\
\text { (LCL-UCL) }\end{array}$ & $\begin{array}{l}\mathrm{LC}_{90}(\mathrm{mg} / \mathrm{ml})(\mathrm{LCL}- \\
\mathrm{UCL}\end{array}$ & $\begin{array}{l}\mathrm{LC} 99(\mathrm{mg} / \mathrm{ml}) \\
(\mathrm{LCL}-\mathrm{UCL})\end{array}$ & $\begin{array}{l}\mathrm{x}^{2}(\mathrm{df} 13) \\
\text { (Significant value) }\end{array}$ \\
\hline Neem: & (LCL-UCL) & (LCL-UCL) & (LCL-UCL) & nt value) \\
\hline Ethanol & $\begin{array}{l}1.805(1.606- \\
1.962)\end{array}$ & $3.581(3.188-4.299)$ & $\begin{array}{l}6.261(5.024- \\
9.042)\end{array}$ & $14.384\left(0.347^{\mathrm{a}}\right)$ \\
\hline Chloroform & $\begin{array}{l}0.686(0.638- \\
0.731)\end{array}$ & $1.112(1.029-1.229)$ & $\begin{array}{l}1.648(1.454- \\
1.962)\end{array}$ & $7.564\left(0.871^{\mathrm{a}}\right)$ \\
\hline Water & $\begin{array}{l}3.002(2.736- \\
3.208)\end{array}$ & $5.584(4.888-7.130)$ & $\begin{array}{l}9.262(7.224- \\
14.852)\end{array}$ & $4.605\left(0.983^{a}\right)$ \\
\hline \multicolumn{5}{|l|}{ Mohaneem: } \\
\hline Ethanol & $\begin{array}{l}1.949(1.761- \\
2.107)\end{array}$ & $3.890(3.433-4.740)$ & $6.835(5.43010 .006)$ & $5.149\left(0.972^{\mathrm{a}}\right)$ \\
\hline
\end{tabular}




$\begin{array}{lllll} & 0.695(0.576- & 2.256(1.1763- & 5.886(3.694- & 3.553\left(0.995^{\mathrm{a}}\right) \\ \text { Chloroform } & 0.792) & 3.551) & 14.356) & \\ & 3.536(3.315- & 6.662(5.574-8.891) & \begin{array}{l}10.866(8.216- \\ 18.459)\end{array} & 2.513\left(0.999^{\mathrm{a}}\right) \\ \text { Water } & 3.792) & & \end{array}$

LCL lower confidence limits; UCL upper confidence limits; $x^{2}$ chi-square; df degrees of freedom, aSince the significance level is greater than 150 , no heterogeneity factor is used in the calculation of confidence limits.

of $\mathrm{LC}_{90}$ for these three solvent extracts as follows: neem, Chloroform $(1.112)>$ ethanol (3.581) > water (5.584); mohaneem, Chloroform (2.256) > ethanol (3.890) > water

(6.662). The grading of $\mathrm{LC}_{99}$ for these three solvent extracts as follows: neem, Chloroform (1.648) > ethanol (6.261) > water (9.262); mohaneem, Chloroform (5.886) > ethanol (6.835) $>$ water $\left(\mathrm{LC}_{99}=10.866\right)$. So, for three solvents, chloroform extract of both plants showed highest mortality rate when compared with two other solvents.

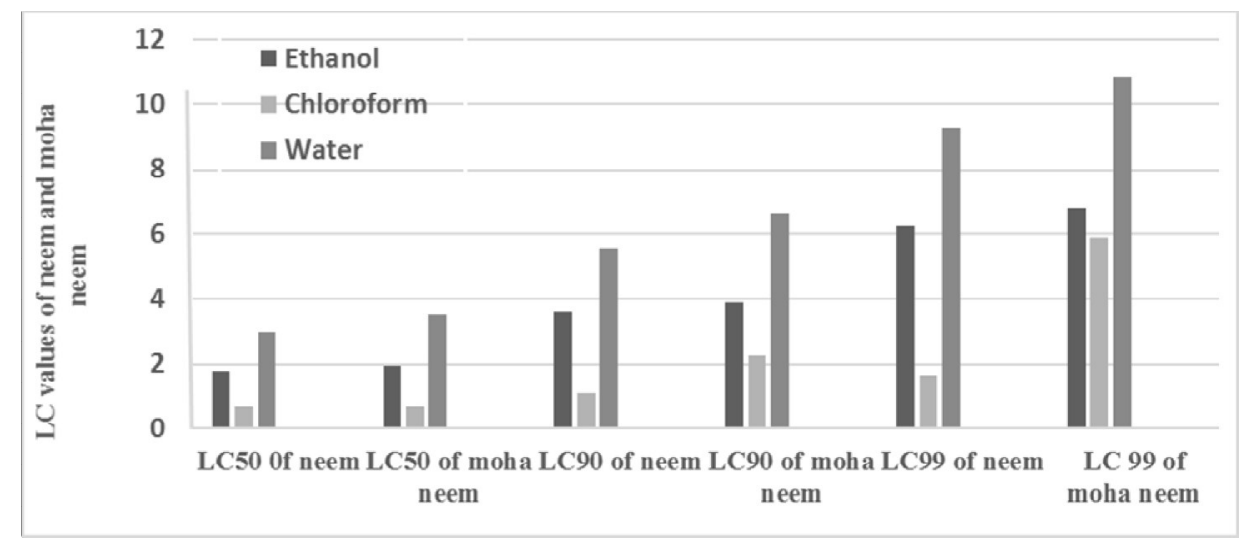

Fig 1. Comparision of lethal concentrations (LC) at three solvent extracts of A. indica and M. azedarach.

Comparison of toxicity following paired t-test for neem and mohaneem: From the above discussion it is apparent that the extracts of the mohaneem (M. azedarach) is less effective than the extracts of the neem ( $A$. indica). To compare between neem and mohaneem solvent extracts, significant paired t-test was followed (Table 3). For the ethanol, chloroform and water extracts of neem and mohaneem, the mean difference was $0.944,1.944$ and 2.556 for which the calculated t-test value is 3.183, 2.331 and 5.569 which were significant (Table 3).

Table 3. Paired t-test with the ethanol, chloroform and water extracts of $A$. indica and $M$. azedarach leaves bioassayed on the fourth instar larvae of $C x$. quinquefasciatus.

\begin{tabular}{l|l|l|l|l|l|l|l}
\hline Solvents & \multicolumn{2}{|l|}{ Dead at each level } & \multicolumn{2}{|l}{ Paired samples } \\
& $\begin{array}{l}\text { Mean of } \\
\text { neem }\end{array}$ & $\begin{array}{l}\text { Mean of } \\
\text { Mohaneem }\end{array}$ & $\begin{array}{l}\text { Mean } \\
\text { difference }\end{array}$ & $\begin{array}{l}\text { SD } \\
\text { (df17) }\end{array}$ & $\begin{array}{l}\text { Standard error } \\
\text { mean }\end{array}$ & $\begin{array}{l}\text { Significant } \\
\text { (2tailed) }\end{array}$ \\
\hline Ethanol & 14.11 & 13.17 & 0.944 & 1.259 & 0.297 & 3.183 & 0.005 \\
Chloroform & 14.78 & 12.83 & 1.944 & 3.539 & 0.834 & 2.331 & 0.032
\end{tabular}




\begin{tabular}{llllllll} 
Water & 12.5 & 9.94 & 2.556 & 1.947 & 0.459 & 5.569 & 0 \\
\hline
\end{tabular}

SD standard deviation, $\mathrm{df}$ degrees of freedom, $\mathrm{t}$ test.

The ethanol extracts of neem $A$. indica at $3.5 \mathrm{mg} / \mathrm{ml}$ dose concentration caused $97.33 \% 4^{\text {th }}$ instar larval mortality (Table 1). Maragathavalli et al. (2012) reported that the ethanol extracts of $A$. indica leaves at $200 \mathrm{mg} / \mathrm{ml}$ dose concentration caused $100 \%$ mortality of the $3^{\text {rd }}$ and $4^{\text {th }}$ instar larvae of $C x$. quinquefasciatus and $90 \%$ mortality of Ae. aegypti. The ethanol extracts of mohaneem $M$. azedarach at $0.5 \mathrm{mg} / \mathrm{ml}(500 \mathrm{ppm})$ caused $45 \%$ larval mortalities of $C x$. quinquefasciatus in 24 hours (Ravichandran et al. 2014). After 36 hours of exposure, the larval mortalities of the mosquito at $2.0 \mathrm{mg} / \mathrm{ml}$ and $3.5 \mathrm{mg} / \mathrm{ml}$ dose concentrations of ethanol leaf extracts of $M$. azedarach were 58.66 and $89.33 \%$, respectively (Table 1 ). The $\mathrm{LC}_{50}$ and $\mathrm{LC}_{90}$ values of the ethanol extracts of neem leaves bioassayed on the $4^{\text {th }}$ instar larvae of $C x$ quinquefasciatus mosquito were 1.805 and $3.581 \mathrm{mg} / \mathrm{ml}$, respectively (Table 2) while $\mathrm{LC}_{50}$ and $\mathrm{LC}_{90}$ values of the same extracts of neem bioassayed on the same mosquito species were found to be $0.565 \mathrm{mg} / \mathrm{ml}$ and $2.39 \mathrm{mg} / \mathrm{ml}$, respectively (Ravichandran et al. 2014). The above findings indicate that the toxicity of the neem leaves used in the present study seem to have less toxic potentiality than the neem leaves used by Ravichandran et al. (2014), but seem to have higher toxic potential than the neem leaves used by Maragathavalli et al. (2012).

The chloroform extracts of $A$. indica leaves at $1.50 \mathrm{mg} / \mathrm{ml}$ dose concentration caused $100 \%$ of $4^{\text {th }}$ instar larval mortality of $C x$ quinquefasciatus (Table 1.). Chakaravarthy et al. (2011) reported that the chloroform extracts of the same plant $A$. indica produced maximum $87 \%$ mortality of $C x$. quinquefasciatus larvae at $1 \mathrm{mg} / \mathrm{ml}(1000 \mathrm{ppm})$ in 24 hours; $\mathrm{LC}_{50}$ and $\mathrm{LC}_{90}$ were $0.198 \mathrm{mg} / \mathrm{ml}(198.32 \mathrm{ppm})$ and $1.15 \mathrm{mg} / \mathrm{ml}(1147.5 \mathrm{ppm})$, respectively. In the present study the chloroform extracts of mohaneem $M$. azedarach at $1.50 \mathrm{mg} / \mathrm{ml}$ caused $84 \%$ mortality of the $4^{\text {th }}$ instar larvae of $C x$ quinquefasciatus.in 36 hours (Table 1). The chloroform extracts of $M$. azedarach caused $35 \%$ mortality of $C x$. quinquefasciatus larvae at $0.5 \mathrm{mg} / \mathrm{ml}$ (1500 ppm) in 24 hours (Ravichandran et al. 2014).

The $\mathrm{LC}_{50}$ and $\mathrm{LC}_{90}$ values of chloroform extracts of mohaneem $M$. azedarach leaves bioassayed on the $4^{\text {th }}$ instar larvae of $C x$ quinquefasciatus mosquito were $0.695 \mathrm{mg} / \mathrm{ml}$ and $2.256 \mathrm{mg} / \mathrm{ml}$, respectively (Table 2) while $\mathrm{LC}_{50}$ and $\mathrm{LC}_{90}$ values of the same extracts of mohaneem bioassayed on the same mosquito species were found to be $0.93 \mathrm{mg} / \mathrm{ml} \mathrm{mg} / \mathrm{ml}$ and $5.65 \mathrm{mg} / \mathrm{ml} \mathrm{mg/ml}$, respectively (Ravichandran et al. 2014).

The water extracts of neem $A$. indica at. 2.50, 3.0, 3.50, 4.0 and $4.50 \mathrm{mg} / \mathrm{ml}$ dose concentrations caused $32.00,56.00,62.66,68.00$ and $81.33 \%$ larval mortalities of $C x$. quinquefasciatus, respectively (Table 1). Aliero (2003) reported that the aqueous leaf extract of A. indica was $83 \%$ mortality of Anopheles mosquito when the larvae were treated with 20 $\mathrm{ml}$ extract while $75 \%$ and $68 \%$ mortality were recorded with 10 and $5 \mathrm{ml}$ extracts, respectively after 12 hours.

Kubmarawa et al. (2008) reported that the most important substance present in A. indica include alkaloids, glucocides, sterids, flavonoids, fatty oils, resins, mucilages, tannins, gums, phosphorus and calcium for cell growth, replacement and body building. Among the limnoids of $M$. azedarach, azadirachtin has been found to be the main ingredient for fighting insects 
and pests, being upto $90 \%$ effective in most instances (Azam et al. 2013). It can also be suggested that the two plants have a number of chemical components, which may be responsible for the many pharmacological actions. Furthermore, the crude extracts may be more effective compared to the individual active compounds, due to natural synergism that discourages the development of resistance in the vectors (Maurya et al. 2007). Finally, it may be suggested that the leaf extracts of neem ( $A$. indica) and mohaneem ( $M$. azedarach) act as a natural larvicidal for controlling mosquitoes. Both these plants are easily available, environmentaly friendly and less expensive for controlling mosquitoes. More research is needed to develop an easy, economically viable and sustainable method to isolate the main toxic ingredients particularly azadirachtin from both neem and mohaneem in order that these insecticidal ingredients may be commercially produced and effectively applied in the country for controlling the insect pests.

\section{References}

Abbott, W.S. 1925. A method of computing the effectiveness of insecticides. J. econ.Entomol. 18 (2): 267-269.

Ahmed, M.F., A.S. Rao, S.R. Ahemad and M. Ibrahim. 2012. Phytochemical studies andantioxidant activity of Melia azedarach Linn leaves by dpph scavenging assay. Int.J.Pharm. Applicat. 3(1): 271-276.

Ahmed, T.U. 1987. Checklist of the mosquitoes of Bangladesh. Mosquito Systematics. 19: 19-204.

Aliero, B.L. 2003. Larvicidal effects of aqueous extracts of Azadirachta indica (neem) on the larvae of Anopheles mosquito. African J. Biotech. 2(9): 325-327.

Alouani, A., N. Rehimi and N. Soltani. 2009. Larvicidal Activity of a Neem Tree Extract (Azadirachtin) Against Mosquito Larvae in the Republic of Algeria. Jord. J.Biol. Sci.2(1): 15-22.

Ameen, M., R.M. Shahjahan, H.R. Khan and A.K.A. Chowdhury. 1985. Larvicidal effects of indigenous Derris elliptica root on Aedes aegupti (Diptera: Culicidae). Itern. Quart.Entomol. 1: 39-43.

Ameen, M., A.K.A. Chowdhury. H.R. Khan and R.M. Shahjahan. 1983a. Insecticidal properties of Derris elliptica (Wall.) (Leguminosae:Papilionaceae) roots against the larvae of Culex fatigans Wied. (Diptera: Culicidae). Dhaka Univ. Stud. B 31(1): 1-11.

Ameen, M., R.M. Shahjahan., H.R. Khan and A.K.A. Chowdhury. 1983b. Toxicity of rotenone extracted from indigenous Derris roots on mosquito larvae. J. Bangladesh Acad. Sci. 7(1\&2): 39-47.

Azam, M.M., Mamun-Or-Rashid, A.N.M. Towfique, N.M. Sen and M.K. Nasrin. 2013.Pharmacological Potentials of Melia azedarach L. - A Review. Am. J. Bio. Sci.1(2):44-49.

Batabyal, L., P. Sharma, L. Mohan, P. Maurya and C.N.A. Srivastava. 2007. LarvicidalEfficiency of Certain Seed Extracts against Anopheles Stephensi, with Reference to Azadirachta indica. J. Asia Pac. Entomol. 10(3): 251-255

Begum, A., M.A. Hamid and M. Elias. 1996. The ecology and seasonal fluctuations of mosquito larvae in a lake of Dhaka city. Bangladesh J. Zool. 14(1): 41-18.

Bilkis, S. 1997. Effect of food on various developmental characteristics of Culex quinquefasciatus (Say) (Diptera: Culicidae) and the predation of its larvae by some predators. M.Sc. thesis, Department of Zoology, University of Dhaka, Dhaka 1000.

Finney, D.J. 1971. Probit analysis. Cambridge University press, London. 68-78 pp.

Ghosh, A., N. Chowdhury, and G. Chandra. 2012. Plant extracts as potential larvicides, Ind. J. Med. Res. 135: 581-598. 
Kazembe, T. and C. Makusha. 2012. Evoluation of mosquito Repellencies of Capsicum frutescens, Carica papaya and Cyanodon dactylon Extracts and Extract Mixtures, Bull. Environ, Pharmacol. Life Sci. 7: 34-40.

Kamaraj, C., A. Bagavan, G. Elango, Z.A. Abduz, G. Rajakumar, S. Marimuthu, T. Santhosh Kumar and A. Rahuman. 2011. Larvicidal activity of medicinal plant extracts against Anopheles subpictus and Culex tritaeniorhynchus, Ind. J. Med. Res. 134(1): 101-106.

Khan, H.R., T. Akter, M.S. Farid, M.M. Islam and M.R. Karim. 2015. Seasonal fluctuations of various mosquito species in two wards of Dhaka city. Physiol. Ecol. \& Environ. Sci. 5(1 $\& 2): 51-58$.

Khan, H.R., M. Mujahid, T. Akter, M.R. Karim and M.S. Farid. 2014. Mosquito diversity in the two wards of Dhaka city. Dhaka Univ. J. Biol. Sci. 23(1): 17-26.

Kubmarawa, D., M.E. Khan, A.M. Punah and Hassan. 2008. Phytochemical Screening and antibacterial activity of extracts from Pakia Clapperotoniana keay against human pathogenic bacteria. J. Med. Plants Res. 2(12): 352-355.

Maragathavalli, S., S. Brindha, N.S. Kaviyarasi, B. Annadurai and S.K. Gangwar. 2012. Mosquitoes larvicidal activity of leaf extract of neem (Azadirachta indica). Int. J. Adv. Biol. Res. 2: 138-142.

Maurya, P., L. Mohan, P. Sharma, L. Batabyal and C.N. Srivastava. 2007. Larvicidal efficacy of Aloe barbadensis and Cannabis sativa against the malaria vector Anopheles stephensi. Entomol. Res. 37: 153-156.

Naganishi, K. 1975. Structure of the insect antifeedant azadirachtin. In: Recent advances in phytochemistry, VC Runeckles (ed.), Plenum, New York. Vol 5: pp. 283-298.

Nathan, S.S., K. Kalaivani and K. Murugan. 2005. Effects of neem limonoids on the malaria vector Anopheles stephensi Liston (Diptera: Culicidae). Acta Trop. 96(1): 47-55.

Nathan, S.S., G. Savitha, D.K. George, A. Narmadha and L. Suganya. 2006. Efficacy of Melia azedarach L. extract on the malarial vector Anopheles stephensi Liston (Diptera: Culicidae). Biores. Tech. 97: 1316-1323.

Nour, A.H., S. Jessinta and A.H. Nour. 2012. Larvicidal activity of extracts from different parts of neem (Azadirachta indica) against Aedes aegypti mosquitoes' larvae. Sci. Res. Essays 7: 2810-2815.

Ravichandran, R., D. Thangaraj and M. Alwarsamy. 2014. Antimosquito Acitvity of Leaf Extract of Neem (Melia azedarach) and Papaya (Carica papaya) detected against larvae of Culex quinquefasciatus. Int. J. Inno. Res. Sci. Eng. Tech. 3(4): 11928-11935.

Wandscheer, C.B., J.E. Duque, M.A.N. Silva, Y. Fukuyama, J.L. Wohlke, J. Adelmann and J.D. Fontana. 2004. Larvicidal action of ethanolic extracts from fruit endocarps of Melia azedarach and Azadirachta indica against the dengue mosquito Aedes aegypti. Toxicol. 44: 829-835. 